\title{
Determinants of
}

Internationalisation - Do they

Differ among Sectors and

\section{Business Functions?}

\section{Evidence from Firm-level Data}

\section{Working Paper}

\section{Author(s):}

Arvanitis, Spyros; Hollenstein, Heinz; Stucki, Tobias

Publication date:

2013-01-01

\section{Permanent link:}

https://doi.org/10.3929/ethz-a-010034068

Rights / license:

In Copyright - Non-Commercial Use Permitted

Originally published in:

KOF Working Papers 348 


\section{KOF Working Papers}

Determinants of Internationalisation - Do they Differ among Sectors and Business Functions?

Evidence from Firm-level Data

Spyros Arvanitis, Heinz Hollenstein and Tobias Stucki 


\section{KOF}

ETH Zurich

KOF Swiss Economic Institute WEH D 4

Weinbergstrasse 35

8092 Zurich

Switzerland

Phone +41446324239

Fax +41446321218

www.kof.ethz.ch

kof@kof.ethz.ch 


\title{
Determinants of Internationalisation - Do they Differ among Sectors and Business Functions?
}

\author{
Evidence from Firm-level Data
}

Spyros Arvanitis

ETH Zurich, KOF Swiss Economic Institute

CH-8092 Zurich

Phone: +41 446325168

Fax: +41 446321234

E-Mail: arvanitis@kof.ethz.ch
Heinz Hollenstein

ETH Zurich, KOF Swiss Economic Institute

CH-8092 Zurich

Phone: +41446324238

Fax: +41 446321234

E-Mail: hollenstein@kof.ethz.ch

Tobias Stucki

ETH Zurich, KOF Swiss Economic Institute

CH-8092 Zurich

Phone: +41 446326307

Fax: +41 446321234

E-Mail: stucki@kof.ethz.ch 


\begin{abstract}
The relevance of services FDI strongly increased over the last two decades. As goods and services differ with respect to important characteristics, one may expect that the determinants of internationalisation are not identical in manufacturing and the service sector. However, there is practically no firm-level research contrasting the two sectors in this respect. In order to fill this gap, we seek to identify for manufacturing and services, firstly, the determinants of a firm's propensity to go international (exports and/or foreign direct investment) and, secondly, the factors determining the complexity of a firm's direct foreign activities in terms of business functions. We find that an OLI-based model can be used to explain not only the propensity to go intenational but also differences between two specific forms of direct foreign investment for both the manufacturing and the service sector.
\end{abstract}

Keywords: Manufacturing vs. services internationalisation; offshoring vs. exports; internationalisation of business functions; multinational companies; international business strategy

JEL classification: F23 


\section{Introduction}

Over the last twenty years, the long-term trend of an increasing share of service sector FDI has accelerated (Dunning and Lundan, 2008; Kundu and Merchant, 2008). Nevertheless, empirical research on FDI is still concentrated on manufacturing. As the basic characteristics of services and goods differ - the main specifics of services are intangibility, inseparability of production and consumption, heterogeneity, perishability as well as ownership (Buckley et al., 1992) - one would expect that the determinants of internationalisation are not the same in the two sectors (see, among many others, Boddewyn, 1986; Dunning, 1989; Contractor et al., 2003). This may hold true although the separation line between goods and services is rather blurred (see, e.g., Grönroos, 1999; Jack et al., 2008). This applies all the more as the service content of manufacturing is continuously increasing and at the same time there is a tendency towards an industrialisation of service provision (Miozzo and Miles, 2002; Guerrieri and Meliciani, 2005).

Against this background, it is deplorable that firm-level empirical research dealing with the internationalisation of service firms is scarce what is true particularly with respect to econometric analyses. Moreover, there are only few empirical studies that cover the whole service sector, and there is hardly any work dealing with the differences between manufacturing and services firms.

For services firms, the analysis of internationalisation is dominated until now by studies for specific industries. To mention are, in particular, financial services, ICT/software, the hotel industry, business services and retail trade (see the comprehensive review of Kundu and Merchant (2008). ${ }^{1}$ The majority of contributions are case studies or small-sample descriptive analyses dealing with one or very few service industries. Econometric studies dealing at firm level with specific service industries became available, with some exceptions, only in recent years: Narayanan and Bhat (2010), Lin (2010) for ICT/software; Villar et al. (2012), LeónDarder et al. (2010), Brown et al. (2003), Contractor and Kundu (1998) for the hotel industry; Mariscal et al. (2012), Nachum and Wymbs (2005), Ursacki and Vertinsky (1992) for financial services; Rodriguez and Nieto (2012) and Terpstra and Yu (1988) for knowledgeintensive service industries.

The concentration on industry-specific studies may be due to the absence of (large scale) datasets covering the whole service sector (Castellacci, 2010) as already pointed out in some earlier review articles (e.g., Coviello and McAuley, 1999). Another reason is perhaps the presumption that the service sector is particularly heterogeneous (hard vs. soft services;

\footnotetext{
${ }^{1}$ For an earlier survey see Knight (1999).
} 
knowledge-intensive vs. capital-intensive services, etc.), what is consistent with Dunning (1989) who argues that type and combination of O-, L- and I-advantages differ quite substantially across service industries. Therefore, Boddewyn et al. (1986) even stated that industry-specific studies of services internationalisation might be more fruitful than the analysis of the entire service sector.

However, there is a number of econometric firm-level studies that cover the entire or large parts of the service sector dealing with specific aspects of internationalisation: entry mode choice (e.g., Brouthers and Brouthers, 2003; Erramilli and Rao, 1993); outsourcing (Jaklic et al., 2012; Murray and Kotabe, 1999); relationship between FDI in manufacturing and business services (Nefussi and Schwellnus, 2010); impact of internationalisation on firm performance (Contractor et al., 2003); determinants of FDI (Kundu et al., 2008; Li and Guisinger, 1992).

Rare are econometric studies that aim at identifying similarities and differences between services and manufacturing firms based on econometric estimates of the same model for both sectors. Examples are the already mentioned studies of Brouthers and Brouthers (2003) and Jaklic et al. (2012). Moreover, Py and Hatem (2009) estimated a model explaining the location of FDI projects differentiated by business functions, and Lejpras (2009) compared manufacturing and services in terms of the factors determining the type of internationalisation (exports, FDI or both). All in all, the empirical knowledge with respect to the specifics of the internationalisation of the two sectors is very limited (Merchant and Gaur, 2008).

The present study, firstly, aims at identifying the determinants of the internationalisation of firm activity distinguishing between manufacturing and services. Secondly, it seeks to explain for the two sectors differences between specific forms of internationalisation that differ regarding their complexity in terms of business functions located abroad. There is practically no econometric work dealing with the first topic, and the second one, to the best of our knowledge, has never been investigated at all.

In order to analyse these topics we formulate two empirical models taking the well-known OLI paradigm as theoretical point of reference. In model I ("INT_propensity"), we estimate the probability of a firm belonging to one of the following three categories: "selling on domestic markets only" (DOMESTIC), "serving, additionally, export markets (without any offshoring)" (EXPORT), and “offshoring” (FDI). In Model II ("INT_complexity"), we determine the likelihood of a firm to locating abroad specific (combinations of) business functions, i.e. a firm belonging (besides to DOMESTIC and EXPORT) to one of two categories of FDI, namely "offshoring distribution and/or production" (FDI_DP) and "performing abroad, in addition to FDI_DP, research and development" (FDI_RDP). 
The present analysis is an extension of Hollenstein (2005) who estimated, based on Swiss firm data for 1998, models which are structurally similar to model I and II but did so only for the entire business sector, thus without distinguishing manufacturing and services. The research also goes beyond Lejpras (2009) who disaggregated the business sector in manufacturing and services and estimated a model that is comparable with our model I which distinguishes between two types of foreign activities, namely exporting only and direct foreign presence. In contrast to our model II, there is no splitting of firms with foreign direct presence into any subcategories.

The paper is based on a large dataset containing information from 1921 companies of the Swiss business sector that responded to a comprehensive survey conducted in 2010 among a representative sample of firms. The available data allow a rich specification of the explanatory part of the two models. By estimating model I and II we are able to significantly add to previous evidence on the differences between manufacturing and service companies with respect to the determinants of international activities. The Swiss case may be of general interest as the process of internationalisation of its economy is particularly advanced.

The structure of the paper is as follows: In the next section, we present the conceptual framework and the related hypotheses. In Section 3, we describe the database and give some information on the incidence of international activities of Swiss companies. Section 4 is devoted to model specification, and in Section 5 we present the empirical results and compare them with previous work. Finally, we summarise and draw some conclusions.

\section{Conceptual framework and related hypotheses}

\subsection{Theoretical background}

Since Hymer (1976) the theory of international investment of firms is based on the assumption of imperfect markets. Under such conditions firm-specific capabilities become a key element that can be successfully exploited abroad independently of the economic attractiveness of different locations (see also Caves, 1982 and, more formalised, the "new trade theory", e.g., Helpman, 1984). Further, the "transaction cost theory" hypothesises that a firm engages in FDI whenever the costs of setting up and running a transnational organisation of activities are lower than those of external market transactions, for example, when external procurement of key components cannot guarantee the required quality (Williamson, 1985; Rugman, 1981, Hennart, 1982; Buckley and Casson, 1985). In addition, there is a whole number of partial hypotheses explaining specific aspects of internationalisation which are rooted in different sub-disciplines of economics such as industrial organisation, management sciences, evolutionary economics, finance, etc. (Dunning, 2000). 
It was already in the 1970 s that Dunning argued that no single approach is able to fully explain a firm's international activity. He proposed as a framework of analysis an eclectic theory of international production, the "OLI paradigm", which he further developed over the years to take account of changing features of the international economy and new theoretical approaches. In its most recent version (Dunning and Lundan, 2008; see also Dunning, 2000), it can be applied not only to the internationalisation of production but also to that of other business functions. Moreover, it clearly considers the network character of the international economy characterised by international partnerships and alliances that increasingly complement hierarchical governance modes. The OLI paradigm now also emphasises more explicitly the strategic aspects of internationalisation reflecting the "resource-based view" (Wernerfelt, 1984) or "dynamic capability view" of the firm (Teece et al., 1997), and, similarly, the concept of the "knowledge-based company" (Kogut and Zander, 1993).

The OLI paradigm serves as theoretical framework for the specification of the explanatory part of the two models estimated in this paper, with the first one explaining the propensity of firms to internationalise their activities (model I: INT_propensity), and the second one explaining the probability of firms to locating abroad specific (combinations of) business functions (model II: INT_complexity).

The OLI approach accounts for three groups of explanatory variables: "ownership-specific advantages" (O), "location-specific advantages" (L) and "internalising advantages" (I). Oadvantages refer to firm-specific capabilities that make a company superior to local competitors irrespective of general location characteristics. Such advantages arise from the availability of firm-specific knowledge, human capital as well as intangibles related to property rights, organisation, managerial skills, finance, international experience, etc. Ladvantages represent potential gains a firm can realise by optimising its activities along the value chain across locations. This type of advantages roots in differences between foreign and domestic locations with respect to factor costs, political stability, the regulatory framework, distance, etc. I-advantages can be realised by setting-up foreign subsidiaries or by international M\&A activities. To a lesser extent, this also holds for equity-based joint ventures or non-equity co-operations if the partners commit themselves on a continuing basis (Dunning and Lundan, 2008). These governance modes enable the firms to reduce risks and costs of transactions in imperfect markets (e.g., for technology or key intermediate products), to mitigate appropriability problems and to facilitate the access to foreign markets.

There are three additional factors that are related to key elements of the OLI model. A first one is firm size that captures size-related O-advantages (e.g., privileged access to capital markets) and I-advantages (e.g., superiority of large companies in international management). Secondly, the market environment (competition, market growth) may influence a firm in its 6 
decision to extend its activities to foreign locations (e.g., "follow the leader" strategy). The third factor refers to industry affiliation as the relevance of certain O-, L- and I-advantages are expected to differ among industries, in particular in the service sector (Dunning, 1989).

\subsection{Hypotheses}

The OLI model implies that $\mathrm{O}$ - and I-advantages of firms and L-advantages of foreign locations positively affect the probability of a company of being directly present abroad, while O-advantages suffice to explain the choice of an exclusively export-based strategy of internationalisation (model I). We thus postulate:

H1: The OLI paradigm is well-suited as theoretical concept for explaining why a firm internationalises its activities (a) in terms of exports driven primarily by $\mathrm{O}$-advantages and (b) in terms of direct foreign engagement driven by O-, L- and I-advantages.

Several scholars argued that the OLI approach is not only suited to explain the internationalisation of manufacturing firms but, perhaps with some modifications, also that of service companies (Boddewyn, 1986; Dunning, 1989; Buckley et al., 1992). However, it is also emphasised that service industries are heterogeneous in terms of the specific characteristics of services (intangibility, inseparability, heterogeneity, perishability, ownership). As a consequence, each service industry presumably exhibits a distinct pattern in terms of OLI advantages. The heterogeneity of the service sector is a recurring topic in the internationalisation literature: capital-intensive vs. knowledge-intensive services (Contractor et al., 2003); equipment-based vs. people-based services (Thomas, 1978), hard vs. soft services (Erramilli, 1990). For example, Ekeledo and Sivakumar (1998) proposed that "hard services" (where production and consumption mostly are separable) are quite similar to manufacturing in terms of internationalisation, while "soft services" (production and consumption are inseparable) differ in this respect. Moreover, the literature posits that some explanatory factors are more relevant in manufacturing than in services. For example, technology-based O-advantages may primarily be relevant in manufacturing, whereas in the service sector soft and intangible factors (e.g., organisational capabilities) often are more prominent. Finally, several scholars refer to the importance of idiosyncratic and highly situation-specific determinants of the internationalisation of service provision. As a consequence it may be difficult in case of services to find evidence for a general explanatory model such as the OLI approach (Bell, 1995; Lejpras, 2009). ${ }^{2}$ Based on these considerations we posit:

2 Moreover, the explanatory power of the OLI model may suffer in case of the service sector because of difficulties to adequately measuring soft explanatory variables, which seem more important for services than for manufacturing. 
H2: The explanatory power of the OLI model is lower in the service sector than in manufacturing as indicated by differences among the two sectors with respect to the relative significance of specific OLI variables.

Model II serves to determine how and to what extent the OLI variables can explain, in addition to exporting activities, the offshoring of certain combinations of business functions. We distinguish the offshoring of (a) distribution and/or production, and (b) R\&D activities in addition to distribution and/or production. We presume that the complexity of internationalisation increases with an increase of the number of business functions in foreign locations. As a consequence, we expect that there are discernible differences between the offshoring of business functions of type (a) and type (b) as to the relative significance of the OLI variables. We thus posit:

H3: The OLI paradigm can also be used to identify differences between different forms of internationalisation, particularly those between direct foreign presence in "distribution and/or production" and direct foreign presence in "distribution and/or production and R\&D”.

It seems reasonable to hypothesise that $\mathrm{H} 3$ is valid not only for the business sector as a whole but for manufacturing and services as well. However, the literature provides some arguments implying that in the service sector the relationship between the OLI variables and the complexity of foreign activity is weaker. We thus postulate:

H4: The OLI paradigm can be also used to identify differences between different forms of internationalisation in manufacturing and services, particularly between direct foreign presence in "distribution and/or production" and direct foreign presence in "distribution and/or production and R\&D".

\section{Data and incidence of foreign activities}

\subsection{Data}

The data used in this study stem almost exclusively from the "Swiss Survey on Internationalisation" conducted in spring 2010 with the reference year 2008 (for some variables the period 2006/08). ${ }^{3}$ The survey yielded information on basic firm characteristics (sales, value added, exports, number and qualification of employees, firm age, industry affiliation, etc.); innovative activity ( $R \& D$, sales of innovative products, etc.); co-operation; obstacles to internationalisation; foreign activities differentiated by business functions

\footnotetext{
3 Only the indicators of market conditions (competition, market growth) stem from another source (Swiss Innovation Survey 2008). 
(distribution, franchising, production, sourcing of intermediate products, $R \& D$, etc.), by governance mode as well as by target regions.

The survey was based on a (with respect to firm size) disproportionally stratified random sample of firms with at least five employees which covers the entire business sector: twenty nine industries and three industry-specific firm size classes (with full coverage of large firms). The questionnaire ${ }^{4}$ was sent out to 4533 companies of which 1921 provided valid information. The response rate $(42.4 \%)$ is satisfactory given the demanding questionnaire. The size and industry composition of the final data set is shown in Table A.1 in the Appendix. The number of observations is large enough to separately estimate model I and II for services $(\mathrm{N}=757)$ and manufacturing $(\mathrm{N}=1000)$. The construction and the energy sector $(\mathrm{N}=164)$ are only included in estimates for the business sector as a whole $(\mathrm{N}=1921)$.

A substantial number of variables used for model estimations are measured on a nominal (e.g. R\&D activities yes/no) or an ordinal scale (e.g. obstacles to internationalisation). The ordinal variables, originally measured on a five point-Likert scale, were throughout transformed into dummy variables, with value 1 representing the scores 4 or 5 and 0 standing for the scores 1 to 3 (for details see Table 3).

\subsection{Incidence of foreign activities}

Table 1 provides some information on the extent of the internationalisation of the companies included in the sample. According to the information in row 2 and 3, the majority of firms are internationalised (56\%). Half of them pursue an (exclusively) export-based strategy (category 2 ), the other half is directly active abroad by locating there at least one business function. The share of internationalised companies is much higher in manufacturing (it is particularly large in the high-tech subsector) than in services (above-average share in case of knowledgeintensive services), and it is much lower in the construction/energy sector. The relative importance of the two basic ways of internationalisation (exporting vs. offshoring) is the same in services and manufacturing. The most remarkable result is the outstanding prevalence of companies directly engaged abroad in high-tech manufacturing. Information on the incidence of internationalisation by industry is presented in Table A.2 in the Appendix.

The rows 4 to 7 of Table 1 show for the firms with direct foreign presence (category 3 ) the share of firms having offshored specific (combinations of) business functions (sub-categories $3 \mathrm{a}$ to $3 \mathrm{~d}$ ). It turns out that category $3 \mathrm{c}$ ("distribution/other activities and production/sourcing") is the most prevalent one in the business sector as well as in all subsectors, with the exception of high-tech manufacturing; in the latter case, firms that also locate abroad some R\&D

4 Versions of the questionnaire in German, French and Italian are available at www.kof.ethz.ch. 
activities are the largest group (category 3d). In all subsectors the share of firms that are active abroad with at least two business functions (sum of $3 \mathrm{c}$ and $3 \mathrm{~d}$ ) is higher than that of companies being present with only one business function (sum of $3 a$ and $3 b$ ).

\section{Table 1}

\section{$4 \quad$ Model specification and estimation procedure}

\subsection{Dependent variables and estimation procedure}

Based on estimates of model I we are able to evaluate the hypotheses H1 and H2. The model explains the firms' choice among the following strategies: "selling on domestic markets only" (DOMESTIC); “exporting goods/services but no offshoring” (EXPORT); "being directly present abroad" (FDI). The three types of firms are mutually exclusive unordered categories which constitute the dependent variable "INT_propensity" with values for DOMESTIC, EXPORT and FDI (see Table 2).

Estimates of model II serve to assess the hypotheses H3 and H4. This model reflects the firms' choice among three alternative strategies of internationalisation (and the basic option of remaining solely domestic (DOMESTIC)). The first one (EXPORT) is specified as in model I, whereas the category FDI of model I (direct foreign presence) is replaced by two subgroups related to the offshoring of combinations of business functions: "direct foreign presence in distribution and/or production" (FDI_DP) and "direct foreign presence in distribution and/or production and R\&D” (FDI_RDP). Like in model I, the three types of firms are mutually exclusive unordered categories representing the dependent variable "INT_complexity" with the values DOMESTIC, EXPORT, FDI_DP and FDI_RDP (see Table 2).

\section{Table 2}

The multinomial logit model is an appropriate procedure for estimating the two models as the dependent variables are nominal variables for mutually exclusive categories of firms. Both models are estimated for the entire business sector and, what is at the core of our interest, separately for manufacturing and services. We throughout use the same set of explanatory variables, expecting that their impact differs depending on (i) the specific categories of firms taken into consideration in the dependent variable of model I or model II and (ii) the sample on which the estimates are based (business sector, manufacturing, services). Estimation of model I yields two parameter vectors, one referring to DOMESTIC, the other one to FDI, whose significance is evaluated against the reference category EXPORT. From the estimates of model II we present here only the parameter vector for FDI_RDP (with FDI_DP as reference category). 
As the econometric analysis is based on cross-section data, the estimated coefficients are suspicious of being endogenous. This problem, to some extent, is attenuated as a substantial number of the explanatory variables can be considered to have a structural character, thus are only slightly changing over time (e.g., the share of employees with tertiary-level education or the existence of R\&D activities). Nevertheless, we cannot evade the general endogeneity problem inherent in cross-section analyses. Therefore, rather than making causal claims, we interpret the estimated coefficients as partial correlations that still allow to assess whether the empirical results are in line with the hypotheses.

The problem of "common method variance" (see Chang et al., 2010; Podsakoff and Organ, 1986), which may affect model estimates if dependent and independent variables are based on (subjective) assessments stemming from the same survey, does not apply in the present case. In our model, the dependent variables do not reflect any subjective judgments but are objective measures of firm characteristics ("is the firm exporting goods/services yes/no", "is the firm directly present abroad yes/no", etc.). The same holds true for many explanatory variables (e.g. "is the firm active in R\&D yes/no", "share of employees with an academic degree").

\subsection{Explanatory variables}

The explanatory variables are supposed to capture the most important aspects of O-, L- and Iadvantages, the firms' market environment and some control variables (industry affiliation, foreign ownership, etc.). The exact definition of the explanatory variables is found in Table $3 .^{5}$

\section{O-advantages}

This category of variables reflecting firm-specific capabilities and assets is expected to be positively related to a firm's international activity. We include, firstly, two indicators of the innovation capacity of firms: in-house $R \& D(r \& d)$ and sales share of new/significantly improved products (inno_sales). Further, we take into consideration the use of high-level human resources (tertiary_academic). We also take account of knowledge protection (appropriability), which is captured by patenting and other legal rights (brands, copyrights) as well as by informal protection mechanisms (e.g., time lead, secrecy). Finally, we consider a firm's international experience, which is a core variable of the stages view of internationalisation. Experience is measured by the age of a company (firm_age) and the relevance of experience-related obstacles to foreign engagements (obst_experience). Firm

5 See Table A.4 in the Appendix for the descriptive statistics of the model variables. 
age should be positively related to internationalisation, whereas we expect a negative sign for the obstacle variable as it is inversely related to foreign experience.

\section{L-advantages}

L-advantages are only relevant for a firm's decision on whether internationalisation should take place by way of exporting goods/services or offshoring. L-variables are captured by the firms' assessments of the relevance of a set of location-related obstacles to a firm's internationalisation. As these represent disadvantages of foreign locations compared to Switzerland, we expect a negative impact on direct foreign presence. ${ }^{6}$ The L-part of the empirical model is made up by eight measures of obstacles which according to an exploratory analysis are the (statistically) most pertinent ones. In accordance with the gravity model of international trade and investment our model contains variables representing the geographical and cultural distance between Switzerland and foreign locations (obst_distance, obst_culture). Further, we consider high costs of being present abroad (obst_cost). We also insert some measures depicting a set of regulation-related L-disadvantages of foreign countries: restrictive regulatory framework in general (obst_regulation); obligation to generate locally a large share of value added (obst_value); forced technology transfer to local firms/institutions (obst_tech_transfer); insufficient enforcement of IPRs in host countries (obst_IPR_protection). Finally, we include a measure of the relevance of political instability of foreign locations for internationalisation (obst_instability). ${ }^{7}$

\section{I-advantages, firm size}

According to transaction cost theory, I-advantages are relevant only for the choice among different modes of foreign engagements (e.g., wholly-owned affiliates vs. joint ventures vs. contractual co-operations). However, efficient control on foreign activities does not necessarily require full ownership; it even may be ensured in longstanding non-equity cooperations (Dunning and Lundan, 2008). I-advantages may thus also influence the choice between offshoring and exporting (but are irrelevant for the basic decision to go international).

6 We only compare the advantages of Switzerland with the rest of the world as we do not have at our disposal information on locational disadvantages differentiated by (groups of) host countries.

7 Based on the exploratory analysis of the obstacles to being present abroad, we did not include some other potential impediments for which the "Swiss Internationalisation Survey 2010" provided data. To mention are high coordination costs, high financial risks, insufficient finance, restrictions to the transfer of profits, legal uncertainties, lack of qualified manpower. For some of these obstacles it is quite surprising that they seemingly are not relevant. This (partly) is due to correlations with obstacles that we included in the model (e.g. correlation of obst_instability with "legal uncertainty", or obst_cost with "high financial risks" and "insufficient finance". 
At the empirical level, I- advantages are difficult to capture. We assume that large firms are in a better position than small ones to reduce transaction costs by internalising market relationships: economies of scale in the governance of foreign affiliates, joint ventures and international co-operations; higher power to bargain with foreign units; advantages in monitoring quality-standards to be met by affiliates; etc. Firm size is thus an overall indicator of I-advantages (although, as already mentioned, it also captures some size-related, not explicitly specified O-advantages). Firm size is measured by the number of employees (size) and, to account for a possibly nonlinear relationship, by its square $\left(s i z e^{2}\right)$. For the quadratic term we expect an insignificant or a negative coefficient, the latter meaning that firm size only matters up to a certain threshold. Finally, we presume that experience gained from cooperating with domestic companies (cooperation) enhances a firm's capability to internalise market relationships at the international level. ${ }^{8}$

\section{Market environment}

We expect that intensive competition on a firm's markets (competition) enforces a company to become active at foreign locations or is an incentive to do so ("follow the leader" or "first mover" strategy). Furthermore, strongly growing world markets in the field of a firm's activities (demand_trend) is another incentive for international engagements. We thus expect for both variables a positive sign.

\section{Control variables}

We control for the fact that foreign-owned companies (foreign) often are primarily oriented towards the Swiss market. Likewise, we account for the fact that some domestic companies do not aim at all to expand beyond the regional market (regional_market). We thus expect for both variables a negative sign. Finally, we insert a large set of industry dummies to control for an omitted variable bias and to make sure that the explicitly specified variables effectively capture behavioural differences among firms rather than industry-specific characteristics (which according to many scholars strongly influence the type of international activity). ${ }^{9}$

Table 3

\section{$5 \quad$ Results}

\subsection{Model I: INT_propensity}

\subsubsection{Business sector $(\mathrm{H} 1)$}

\footnotetext{
8 As (long-lasting) co-operations with foreign partners are an element of the dependent variable, we may only account for experience gained from domestic co-operation.

9 In a strict sense this holds true only if the industry dummies are uncorrelated with the firm-specific explanatory variables. 
To start with, we indicate how to read the results presented in Table 4 (columns 1 and 2). Remember that the coefficients of the variables explaining DOMESTIC and FDI are evaluated against the respective parameters for the firms that are internationally active solely through exports (EXPORT). Therefore, a statistically significant negative sign for the coefficient of DOMESTIC in combination with a significant positive sign of the coefficient for FDI (denoted as DOMESTIC $<$ EXPORT $<$ FDI) for $\mathrm{O}$ - and I-variables indicates a monotonically increasing positive effect of a certain variable on a firm's internationalisation, thus extending activities from only domestic activities to exports and further to FDI (see, e.g., variable $r \& d$ ). This can be the case also partially, namely if the coefficient only increases

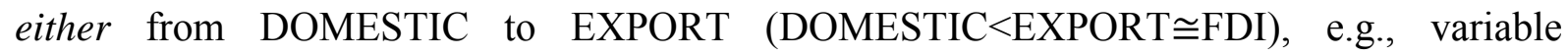

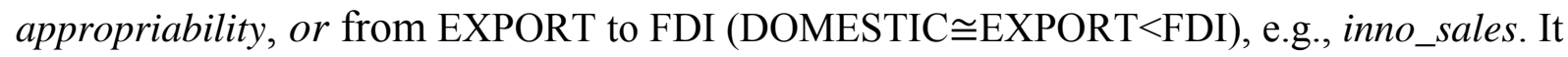
is the other way round in case of the O-related obstacle "lack of foreign experience" ("obst_experience") as it represents a disadvantage of a firm; in this case, we expect an increasing positive effect if DOMESTIC $>$ EXPORT $>$ FDI. Similarly, as L-related obstacles reflect disadvantages of host countries, offshoring is preferred to exporting if EXPORT $>$ FDI. L-disadvantages are irrelevant for the shift from DOMESTIC to EXPORT; we thus expect no significant coefficients in case of DOMESTIC.

\section{Table 4}

The columns 1 and 2 of Table 4 show that O-advantages are important drivers of internationalisation as all coefficients of the O-variables are significantly positive (and, as expected, negative in case of obst_experience). The respective coefficients monotonically increase ( $r \& d$, tertiary_academic), increase partly (inno_sales, appropriability, firm_age) or monotonically decrease in case of the O-related obstacle obst_experience. The O-part of the model is thus strongly supported.

The results for the variables representing L-disadvantages of foreign locations confirm the hypothesis that they are relevant only for the shift from EXPORT to FDI; none of the coefficients for DOMESTIC is significant. In contrast, we find statistically significant effects for the transition from EXPORT to FDI for practically all L-related obstacles. Only four of them show the postulated negative sign, meaning that they deter a firm from being directly active at foreign locations: (large) geographic distance (obst_distance), high costs of internationalisation (obst_cost), obligation to produce locally a significant part of the value added (obst_local_value), and, finally, forced local technology transfer (obst_tech_transfer). We do not find a significant effect for political instability in potential host countries (obst_instability). 
Contrary to our expectations, we obtained for three obstacle variables a positive sign: cultural difference (obst_culture), restrictive regulatory environment (obst_regulation) and insufficient protection of IPRs (obst_IPR_protection). We argue that for these categories of obstacles the positive sign reflects the fact that the firms get aware of the extent of hindrance not until they have already engaged in foreign activities other than exports. Cultural differences that make transactions more difficult, might manifest themselves only as the company has become directly present abroad. As it may be hard to enforce property rights without knowledge of local conditions and without (personal) relationships to local actors, the extent of respective difficulties might not be realized by firms without direct foreign activity. Considerations along similar lines may hold in case of regulatory obstacles where knowledge of local conditions may be necessary to optimally adapting to regulatory restrictions or circumvent them.

All in all, we conclude that the results for the variables reflecting L-disadvantages of host countries are largely consistent with the OLI model.

I-advantages, as expected, are only relevant for the choice between exporting and offshoring. The results for size and cooperation are in line with the hypothesis that firms profiting from Iadvantages prefer a direct foreign presence over an export strategy (FDI $>$ EXPORT). The size effect is positive only up to a certain threshold as indicated by the negative sign of $s i z e^{2}$.

The market environment also exerts a statistically significant influence on a firm's internationalisation. Vigorous competition on (world) product markets (competition) induces or enforces a firm to be present at foreign locations rather than to servicing foreign markets through exports (FDI $>$ EXPORT). Moreover, rising product demand (demand_trend) favours internationalisation above a home-market orientation but does not significantly discriminate

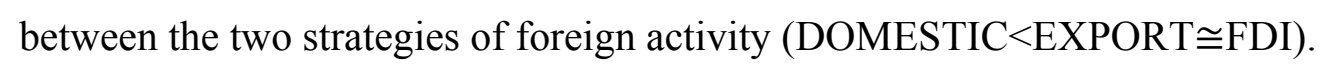

Finally, we get the expected results for the control variables foreign_subsidiary and regional_market. Interestingly, the overall industry effect is small although the industry dummies (industry) are jointly significant. This finding implies that behavioural differences among firms (as well as location factors) are the dominant drivers of foreign activities, whereas the literature emphasised the decisive role of industry-specific factors (see subsection 2.2).

To sum up, the empirical findings confirm the main propositions of the OLI model as there is strong evidence for all constituent parts of the model; the estimates for the entire business sector are thus in line with hypothesis H1. 


\subsubsection{Manufacturing vs. services (H2)}

The columns 3 and 4 of Table 4 show that the OLI model also is confirmed for manufacturing. Model fit and pattern of explanation are similar to that of the business sector as a whole. We thus abstain from commenting the findings for manufacturing companies.

The results for services only partly are in line with the OLI model (columns 5 and 6), but the explanatory power (measured by $\mathrm{R}^{2}$ ) is still satisfactory. In case of $\mathrm{O}$-advantages, the findings are less stringent than those for manufacturing. Diverging from manufacturing, the evidence for L-variables to influencing the service firms' choice between offshoring and exporting rests on only one, but important, variable, namely the high costs of going abroad which strongly deter foreign engagements. The I-part of the model is confirmed in case of manufacturing but not for services. Remarkably, firm size has no effect on the internationalisation of service companies. In both sectors, the market environment is a driver of internationalisation; in this respect, the positive effects are clearly stronger in services than in manufacturing. We conclude that the overall findings do not contradict hypothesis $\mathrm{H} 2$.

A more in-depth inspection of the results yields some explanation for the differences between manufacturing and services. Firstly, it turns out that the O-advantages of manufacturing companies rest to a higher extent than those of services on capabilities related to technology and innovation ( $r \& d$, inno_sales) as well as on experience (obst_experience, firm_age). In contrast, the firms' endowment with highly qualified personnel (tertiary_academic) plays a larger role for explaining the internationalisation of service companies. This difference may indicate that soft capabilities (e.g., management, organisation) create competitive advantages more often in services than in manufacturing.

Secondly, the differences among the two sectors with respect to the relevance of L-advantages and firm size are not as surprising as it looks at first sight. They are partly due to the fact that several indicators of L-variables reflect technology-related problems, which obviously are more relevant in manufacturing. To mention are primarily the forced technology transfer to local actors (obst_tech_transfer) and the insufficient protection of IPRs in the target country (obst_IPR_protection). Other impediments presumably become relevant only if a firm is active abroad by production-oriented activities, which are more prevalent in the manufacturing sector (see Table 1). An example is the variable obst_culture for which we get a positive sign in case of manufacturing (but not for services) reflecting, to some extent, the high costs of controlling foreign (production) activities in culturally different locations. The same argument may partly explain why firm size only matters for manufacturing; the higher monitoring and controlling costs in case of production-oriented foreign activities are easier to bear for large than for small firms. 
To date, only Lejpras (2009) provided separate estimates for manufacturing and services. Based on an OLI-like model this author found for manufacturing that innovativeness, firm size and intensity of competition are the main factors determining why firms, rather than solely selling on domestic markets, also export goods/services and, to a lesser extent, why they are directly present at foreign locations rather than staying at home. In the service sector, the same three variables determine the firms' shift to exporting, but the model could not explain why firms engage in offshoring activities. In contrast to our study, the shift between an exporting strategy and one that also involves FDI is not analysed.

We also compare the findings for the service sector with two papers (no estimates for manufacturing), whose approach may be interpreted in terms of the OLI model (though comparability is limited). Kundu et al. (2008) who analysed FDI in Central/Eastern Europe got some evidence only for L-advantages what, at least partly, is due to the specific country coverage of the sample. Li and Guisinger (1992) found that L-advantages (regulation), the market environment (demand prospects, competition) and firm size are the main drivers of outward FDI of MNEs based in developed countries. These results are in line with our findings in case of the market environment and, perhaps, with respect to L-advantages (in spite of a different specification). The divergence in case of firm size (we did not find a significant size effect in case of services) may be due to the fact that these authors did not account for O-advantages and focused on FDI (and thus neglected non-equity foreign engagements).

\subsection{Model II: INT_complexity}

\subsubsection{Business sector (H3)}

For the business sector as a whole (Table 5, column 1), we find some substantial differences between the internationalisation forms FDI_DP and FDI_RDP for 6 out of 18 OLI-related explanatory variables. The differences with respect to the $\mathrm{O}$-variables refer to the existence of R\&D activities, the share of innovative products and appropriability, which are factors that are more important for the category FDI_RDP than for FDI_DP. The main reason for this difference is that foreign investment in $\mathrm{R} \& \mathrm{D}$ in addition to distribution and/or production is closely related to a high level of innovation activities and the need to seize the innovationbased revenues. With respect to the L-variables there are differences only for the obstacles "lack of sufficient IPR-protection" and "lack of political stability" which obviously are more relevant for firms that engage in foreign $R \& D$ investment. Firm size (as proxy for Iadvantages) is also more important for FDI_RDP than for FDI_DP. There are no differences for the variables representing market conditions and the control variables foreign_subsidiary and regional market. Taking account of the results for model I (shift from DOMESTIC to 
EXPORT and shift from EXPORT to FDI, respectively) according to which the step from home to international activities is substantial in terms of the explanatory variables, our findings may be interpreted as evidence for a gradual process of internationalisation (DOMESTIC $<$ EXPORT $<$ FDI_DP $<$ FDI_RDP) as postulated by the stages view of internationalisation (Johanson and Vahlne, 1977). The findings in Table 5 are in accordance with hypothesis 3 and do not differ much from those of a comparable OLI-based study for the Swiss business sector that used data for 1998 (Hollenstein, 2005).

\section{Table 5}

\subsubsection{Manufacturing vs. services (H4)}

In manufacturing (Table 5, column 2), differences between FDI_DP and FDI_RDP are discernible for 8 out of 18 variables. The pattern of differences is practically the same as in the entire business sector; in addition we find significant effects for some further O-related factors, namely the "share of employees with tertiary-level education" and "experience in foreign activities". These additional effects also are compatible with the specific character and the requirements of foreign $R \& D$ investments. In combination with the results in Table 4 (model I) we interpret these findings as an indication of a gradual and continuous process of internationalisation, what is in line with the stages view of internationalisation (DOMESTIC $<$ EXPORT $<$ FDI_DP $<$ FDI_RDP). The two internationalisation strategies FD_DP and FD_RDP do not differ with regard to market conditions: competition and demand expectations tend to exert an influence primarily on the shift from exports to offshoring in general. All in all, the findings for manufacturing are in line with hypothesis H4.

In case of the service sector (Table 5, columns 3 and 4), the pattern of results differs significantly from that for manufacturing (column 2). Due to multicollinearity between the variables $r \& d$ and tertiary_academic the coefficient for the latter variable becomes significantly negative in the presence of $r \& d$ (column 3). In estimates without $r \& d$ the variable tertiary_academic is insignificant (column 4). Also due to multicollinearity the coefficient of the variable obst_experience is significantly positive in column 3 and becomes insignificant in column 4. We consider the estimates in column 4 as more valid in econometric terms. Hence, our comments refer to these results.

We find differences between FDI_DP and FDI_RDP for 6 of the 17 OLI-related variables. There are some differences with respect to O-advantages (insignificant coefficients for the share of employees with tertiary-level education and appropriability; no effect for experience), but more important are those regarding L-(dis)advantages (significant effects for large distance and obligation to produce locally; no effect for insufficient enforcement of IPRs), 
and I-advantages (propensity to cooperate). The two strategies of internationalisation, like in manufacturing, do not differ with respect to market conditions. The findings, particularly those for the O-variables, reflect specific characteristics of services such as the intensive use of non-technological know-how that does not need to be strongly protected from competition (tacit knowledge) and the smaller differences between production and R\&D as to human capital intensity compared to manufacturing. In combination with the findings for model I (Table 4), the results in Table 5 can be interpreted as a hint that in the service sector the most relevant step that can be explained by the OLI approach is the shift from exclusively domestic activities to internationalisation in general, whereas the specific differences between exporting and direct foreign presence (with or without $R \& D$ ) are less clear-cut than in manufacturing. The pattern of internationalisation in services may thus be characterized as DOMESTIC $<$ EXPORT $\cong$ FDI_DP $<$ FDI_RDP. This finding is in accordance with the existing literature where it is argued that the first step of internationalisation of service companies may often require a direct foreign presence (Carman and Langeard, 1980; Boddewyn et al. 1986; Bell, 1995; Goerzen and Makino, 2007). To sum up, the results for the service sector seem to be in line with hypothesis H4 though not to the same extent as it is the case for manufacturing.

\section{Summary and conclusions}

Empirical research on the internationalisation of firms still focuses on manufacturing. As the characteristics of services and goods differ in several respects it may be expected that the determinants of the firms' international activities are diverging among the two sectors. However, there is hardly any econometric firm-level evidence on whether this proposition holds true. Therefore, the present study aims, firstly, at identifying econometrically the factors determining the internationalisation of firm activity differentiated by manufacturing and services. Secondly, it seeks to explain differences between specific forms of international activities in terms of business functions that may be located abroad, again contrasting the two sectors. The OLI model is used as theoretical background of the empirical analysis that is based on a large firm-level dataset covering the Swiss business sector.

We specified two models that are estimated for the entire business sector and, separately, for manufacturing and services. The first one ("INT_propensity") determines the probability of a company to belonging to one of the following categories of firms: "selling on domestic markets only", "serving, additionally, export markets" and "offshoring". The second model ("INT_complexity") focuses on internationalized companies and determines the probability of a company to belonging to one specific category of such firms: "serving export markets", "offshoring of distribution and/or production", "offshoring of R\&D activities in addition to 
distribution and/or production". The estimates of the two models are largely in line with our hypotheses.

Firstly, the OLI model is well suited to explaining why firms internationalize their activities by means of exporting and/or offshoring (propensity to internationalize). This holds true in particular for the business sector as a whole and for manufacturing, whereas, as hypothesised, the explanatory power of the OLI model is lower in case of the service sector. The latter finding is presumably due to the higher importance of "soft" (intangible) factors in services that are not specified in our model as contrasted with technology-oriented O-variables in manufacturing and the lower relevance of L-variables (particularly those related to knowledge/technology). Consequently, the relative importance of some key explanatory variables differs among the two sectors. Secondly, the OLI model allows to explaining differences between forms of internationalisation that differ in complexity, i.e. "offshoring of distribution and/or production" vs. "offshoring of R\&D, distribution, production". This primarily holds true for manufacturing but tends to be the case also for the service sector. Thirdly, the estimates for both models seem to be consistent with the stages view of internationalisation in the manufacturing sector and, to some extent, also in the service sector.

Considering the results of our investigation and given the lack of studies dealing with the topic of this paper, we substantially add to existing knowledge regarding the determinants of the internationalisation of firm activity. The paper particularly yields new insights by systematically contrasting estimates for manufacturing and services firms, as well as by investigating the determinants of the complexity of internationalisation in terms of business functions. The analysis clearly shows that manufacturing and services companies substantially differ with respect to the determinants of the propensity and the complexity of internationalisation. Nevertheless, the OLI model remains an adequate framework of analysis for both sectors.

The study has a number of limitations that should be addressed in future research. Firstly, it is based on cross-sectional data (what holds true also for the majority of research in this field). Therefore, the results, rather than indicating causal relationships, have to be interpreted as partial correlations; nevertheless, they allow an assessment whether the findings are consistent with the postulated hypotheses. Therefore, econometric studies making use of longitudinal data would be highly welcome. These also could contribute to the analysis of the dynamics of internationalisation. Secondly, in order to improve the explanatory part of the model, it might be beneficial to explicitly specify some of the O-advantages we could capture only in a summary way. This would be valuable, in the first place, for non-technological capabilities that are more relevant in services than in manufacturing. 


\section{References}

Bell, J. (1995): The Internationalisation of Small Computer Software Firms: A Further Challenge to "Stage" Theories, European Journal of Marketing, 29(8), 60-75.

Boddewyn, J.J., Halbrich, M. and A.C. Perry (1986): Service Multinationals: Conceptualization, Measurement and Theory, Journal of International Business Studies, 17(3), 41-57.

Brouthers, K.D. and L.E. Brouthers (2003): Why Service and Manufacturing Entry Mode Choices Differ: The Influence of Transaction Cost Factors, Risk and Trust, Journal of Management Studies, 40, 89-97.

Brown, J.R., Dev, C.S. and Z. Zhou (2003): Broadening the Foreign Market Entry Mode Decision: Separating Ownership and Control, Journal of International Business Studies, 34(4), 393-413.

Buckley, P.J. and M.C. Casson (1985): The Economic Theory of the Multinational Enterprise, McMillan, London.

Buckley, P.J., Pass, C.L. and K. Prescott (1992): The Internationalisation of Services Firms: A Comparison with the Manufacturing Sector, Scandinavian International Business Review, 1(1), 39-56.

Carman, J.M. and E. Langeard (1980): Growth Strategies of Service Firms, Strategic Management Journal, 1(1), 7-22.

Castellacci, F. (2010): The Internationalisation of Firms in the Service Industries: Channels, Determinants and Sectoral Patterns, Technological Forecasting and Social Change, 77(3), 500-513.

Caves, R.E. (1982): Multinational Enterprise and Economic Analysis, Cambridge University Press, Cambridge (Mass.).

Chang, S.-J., van Witteloostuijn, A. and L. Eden (2010): From the Editors: Common Method Variance in International Business Research, Journal of International Business Studies, 41(1), 78-84.

Contractor, F.J. and S.K. Kundu (1998): Modal Choice in a World of Alliances: Analyzing Organizational Forms in the International Hotel Sector, Journal of International Business Studies, 29(2), 325-357.

Contractor, F.J., Kundu, S.K. and C.-C. Hsu (2003): A Three Stage Theory of International Expansion: The Link between Multinationality and Performance in the Service Sector, Journal of International Business Studies, 34(1), 5-18.

Coviello, N.E. and A. McAuley (1999): Internationalisation and the Smaller Firms: A Review of Contemporary Empirical Research, Management International Review, 39(3), 223256.

Dunning, J.H. (1989): Multinational Enterprises and the Growth of Services: Conceptual and Theoretical Issues, The Service Industries Journal, 9(1), 5-39.

Dunning, J.H. (2000): The Eclectic Paradigm as an Envelope for Economic and Business Theories of MNE Activity, International Business Review, 9, 163-190. 
Dunning, J.H. and S.M. Lundan (2008): Multinational Enterprises and the Global Economy, Second Edition, Edward Elgar, Cheltenham.

Ekeledo, I. and K. Sivakumar (1998): Foreign Market Entry Mode Choice of Service Firms: a Contingency Perspective, Journal of the Academy of Marketing Science, 26(4), 274-292.

Erramilli, M.K. (1990): Entry Mode Choice in Service Industries, International Marketing Review, 7(5), 50-62.

Erramilli, M.K. and C.P. Rao (1993): Service Firms' International Entry Mode Choice: A Modified Transaction-Cost Analysis Approach, Journal of Marketing, 57, $19-38$.

Goerzen, A. and S. Makino (2007): Multinational Corporation Internationalisation in the Service Sector: A Study of Japanese Trading Companies, Journal of International Business Studies, 38(4), 1149-1169.

Grönroos, C. (1999): Internationalisation Strategies for Services, Journal of Services Marketing, 13(4/5), 290-297.

Guerrieri, P. and V. Meliciani (2005): Technology and International Competitiveness: The Interdependence Between Manufacturing and Producer Services, Structural Change and Economic Dynamics, 16, 489-502.

Helpman, E. (1984): A Simple Theory of International Trade with Multinational Corporations, Journal of Political Economy, 92, 451-71.

Hennart, J.-F. (1982): A Theory of Multinational Entreprise, University of Michigan Press, Ann Arbor.

Hollenstein, H. (2005): Determinants of International Activities: Are SME's Different? Small Business Economics, 24, 431-450.

Hymer, S. (1976): The International Operations of National Firms: A Study of Direct Foreign Investment. MIT Press, Cambridge (MA).

Jack, R., As-Saber, S., Edwards, R. and P. Buckley (2008): The Role of Service Embeddedness in the Internationalisation Process of Manufacturing Firms, International Business Review, 17, 442-451.

Jaklic, A., Cirjakovic, J. and A. Chidlow (2012): Exploring the Effects of International Sourcing on Manufacturing versus Service Firms, The Service Industries Journal, 32(7), 1193-1207.

Johanson, J. and J.-E. Vahlne (1977): The Internationalisation Process of the Firm. A Model of Knowledge Development and Increasing Foreign Market Commitments, Journal of International Business Studies, 8(1), 22-32.

Knight, G. (1999): International Services Marketing: Review of Research, 1980-1998, Journal of Services Marketing, 13(4/5), 347-360.

Kogut, B. and U. Zander (1993): Knowledge of the Firm and the Evolutionary Theory of the Multinational Corporation, Journal of International Business Studies, 24, 625-45.

Kundu, S.K., Kumar, V. and S.D. Peters (2008): Impact of Ownership and Location Factors on Service Multinationals`Internalisation, The Service Industries Journal, 28(5), 567-580.

Kundu, S.K. und H. Merchant (2008): Service Multinationals: Their Past, Present, and Future, Management International Review, 48(4), 371-377. 
Lejpras, A. (2009): Determinants of Internationalisation: Differences between Service and Manufacturing SMEs, DIW Discussion Papers No. 886, German Institute of Economic Research (DIW), Berlin.

León-Darder, F., Villar-García, C. and J. Pla-Barber (2010): Entry Mode Choice in the Internationalisation of the Hotel Industry: a Holistic Approach, The Service Industries Journal, 31(1), 107-122.

Li, J. and S. Guisinger (1992): The Globalization of Service Multinationals in the "Triad" Regions: Japan, Western Europe and North America, Journal of International Business Studies, 23(4), 675-696.

Lin, F-J. (2010): The Determinants of Foreign Direct Investment in China: The Case of Taiwanese Firms in the IT industry, Journal of Business Research, 63(5), 479-485.

Mariscal, A.S., Zhang, Y. and J.L. Pasqual (2012): Internationalisation of Multinational Banks: a Study of Foreign Direct Investment in Seven Latin American Countries, The Service Industries Journal, 32(7), 1149-1170.

Merchant, H. and A. Gaur (2008): Opening the "Non-Manufacturing" Envelope: The Next Big Enterprise for International Business Research, Management International Review, 48(4), 379-396.

Miozzo, M. and I. Miles (2002): The Relation Between the Internationalisation of Services and the Process of Innovation: a Research Agenda, in: M. Miozzo and I. Miles (Eds.), Internationalisation, Technology and Services, Edward Elgar, Cheltenham (UK), pp.1532 .

Murray, Y.K. and M. Kotabe (1999): Sourcing Strategies of U.S. Service Companies: a Modified Transaction -Cost Analysis, Strategic Management Journal, 20, 791-809.

Nachum, L. and C. Wymbs (2005): Product Differentiation, External Economies and MNE Location Choices: M\&As in Global Cities Journal of International Business Studies, 36(4), 415-434.

Narayanan, K. and S. Bhat (2010): Technology Sourcing and Outward FDI: A Study of IT Industry in India, Technovation, 31(4), 177-184.

Nefussi, B. and C. Schwellnus (2010): Does FDI in Manufacturing Cause FDI in Business Services? Evidence from French Firm-level Data, Canadian Journal of Economics, 43(1), 180-203.

Podsakoff, P.M. and D.W. Organ (1986): Self-Reports in Organisational Research: Problems and Prospects, Journal of Management, 12(4), 531-544.

Py, L. and F. Hatem (2009): Internationalisation et localisation des services: une analyse sectorielle et fonctionnelle appliquée aux firmes multinationales en Europe, Economie et Statistique, 426, 67-95.

Rodriguez, A. and M.J. Nieto (2012): The Internationalisation of Knowledge-intensive Business Services: the Effect of Collaboration and the Mediating Role of Innovation, The Service Industries Journal, 32(7), 1057-1075.

Rugman, A.M. (1981): Inside the Multinationals: The Economics of Internal Markets, Columbia University Press, New York. 
Teece, D.J., Pisano, G. and A. Shuen (1997): Dynamic Capabilities and Strategic Management, Strategic Management Journal, 18, 509-33.

Terpstra, V. and C.-M. Yu (1988): Determinants of Foreign Investment of U.S. Advertising Agencies, Journal of International Business Studies, 19(1), 33-46.

Thomas, D.R.E. (1978): Strategy is Different in Service Business, Harvard Business Review, $56,158-165$.

Ursacki, T. and I. Vertinsky (1992): Choice of Entry Timing and Scale by Foreign Banks in Japan and Korea, Journal of Banking and Finance, 16, 405-421.

Villar, C., Pla-Barber, J. and F. León-Darder (2012): Service Characteristics as Moderators of the Entry Mode Choice: Empirical Evidence in the Hotel Industry, The Service Industries Journal, 32(7), 1137-1148.

Wernerfelt, B. (1984): A Resource-based View of the Firm,. Strategic Management Journal, $5,171-80$.

Williamson, O.E. (1985): The Economic Institutions of Capitalism, Basic Books, New York. 
Table 1: Share of firms by business functions as a percentage of all firms differentiated by sector ${ }^{a}$

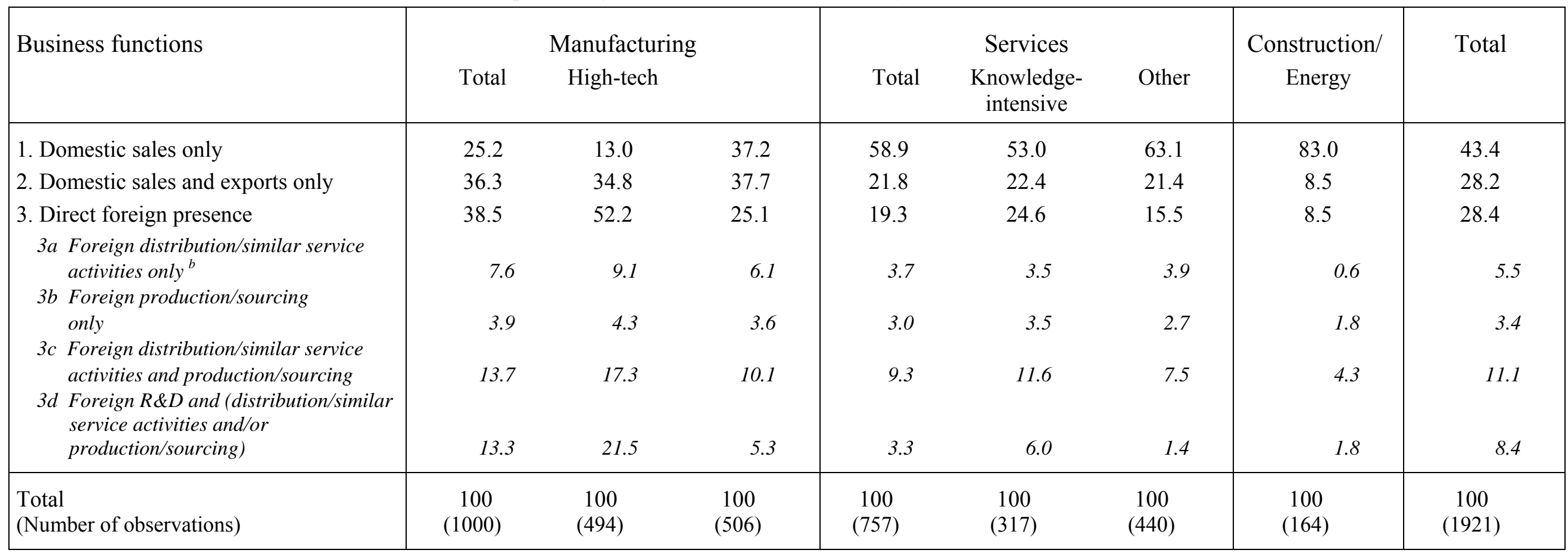

${ }^{\mathrm{a}}$ For the composition of the two subsectors of manufacturing and services respectively, see Table A.1.

b The category "similar service activities" contains, in particular, franchising; licensing; (lasting) management and consulting contracts. 
Table 2: Specification of the dependent variables

\begin{tabular}{|l|l|}
\hline Dependent variable & Definition \\
\hline $\begin{array}{l}\text { Modell I } \\
\text { INT_propensity }\end{array}$ & $\begin{array}{l}\text { The firm belongs to one (and only one) of the following types of firms (yes/no): } \\
\text { DOMESTIC: Firms with domestic sales } \\
\text { EXPORT: Firms with domestic and export sales (but no offshoring) } \\
\text { FDI: Firms with any kind of direct foreign presence (in addition to domestic and } \\
\text { export sales) } \\
\text { EXPORT is used as reference category }\end{array}$ \\
\hline Modell II & $\begin{array}{l}\text { ThT_complexity } \\
\text { DOMESTIC: Firms with domestic sales } \\
\text { EXPORT: Firms with domestic and export sales (but no offshoring) } \\
\text { FDI_DP: Firms having off-shored distribution and/or production } \\
\text { FDI_RDP: Firms having off-shored research and development (R\&D) in addition } \\
\text { to distribution and/or production }\end{array}$ \\
& \begin{tabular}{l} 
FDI_DP is used as reference category \\
\hline
\end{tabular} \\
\hline
\end{tabular}


Table 3: Specification of the explanatory variables of model I to II

\begin{tabular}{|c|c|c|}
\hline $\begin{array}{l}\text { Explanatory } \\
\text { variable }\end{array}$ & Description & $\begin{array}{l}\text { Expected sign in } \\
\text { explaining } \\
\text { INT_propensity and } \\
\text { INT_complexity }\end{array}$ \\
\hline \multicolumn{2}{|c|}{ Ownership-specific advantages (O) } & \\
\hline$r \& d$ & R\&D activities, 2006-2008 (yes/no, dummy variable) & + \\
\hline inno_sales & Sales share of innovative products, logarithm, 2008 & + \\
\hline tertiary_academic & Share of employees with academic education, logarithm, 2008 & + \\
\hline appropriability & Effectiveness of knowledge protection & + \\
\hline & $\begin{array}{l}\text { Dummy variable (high/low effectiveness) based on the average of firm } \\
\text { assessments on a 5-point Likert scale of four means of protection (patents, } \\
\text { trademarks, copyrights, informal mechanisms) }\end{array}$ & \\
\hline firm_age & Age of the firm (years), logarithm & + \\
\hline \multicolumn{2}{|c|}{$\begin{array}{l}\text { O-related obstacle to internationalisation } \\
\text { (Dummy variables based on firm assessments of the relevance on a 5-point Likert scale: value } 1 \text { for scores } \\
4 \text { or 5, otherwise 0) }\end{array}$} & \\
\hline obst_experience & Lack of foreign experience & - \\
\hline \multicolumn{2}{|c|}{$\begin{array}{l}\text { Location-specific advantages (L): L-related obstacles internationalisation } \\
\text { (Dummy variables based on firm assessments of the relevance on a 5-point Likert scale: value } 1 \text { for scores } \\
4 \text { or 5, otherwise } 0 \text { ) }\end{array}$} & \\
\hline obst_distance & Large geographical distance & - \\
\hline obst_culture & Large cultural difference & - \\
\hline obst_cost & High costs of internationalisation & - \\
\hline obst_regulation & Restrictive regulations at foreign locations & - \\
\hline obst_instability & Political instability in target countries & - \\
\hline obst_local_value & Obligation to generate locally a high share of value added & - \\
\hline obst_tech_transfer & Obligation to transfer technology to local actors & - \\
\hline obst_IPR_protection & Insufficient protection of IPRs in target countries & - \\
\hline \multicolumn{2}{|c|}{ Internalising advantages (I), firm size } & \\
\hline size, $\operatorname{size}^{2}$ & Number of employees (in 1000) and its square, 2008 & $+/ ?$ \\
\hline Cooperation & Co-operation with domestic firms (yes/no; dummy variable) & + \\
\hline \multicolumn{2}{|l|}{ Market conditions } & \\
\hline Competition & $\begin{array}{l}\text { Share of firms at the } 3 \text {-digit industry level which are confronted } \\
\text { with strong price competition, } 2008 \\
\text { (firms with an assessment of } 4 \text { or } 5 \text { on a five point Likert scale) }\end{array}$ & + \\
\hline demand_trend & $\begin{array}{l}\text { Share of firms at the } 3 \text {-digit industry level which benefit from } \\
\text { strongly growing markets in the period 2006-2011 } \\
\text { (firms with an assessment of } 4 \text { or } 5 \text { on a five point Likert scale) }\end{array}$ & + \\
\hline \multicolumn{2}{|l|}{ Control variables } & \\
\hline Foreign & $\begin{array}{l}\text { The firm is a foreign-owned subsidiary with primarily local focus } \\
\text { (yes/no; dummy variable) }\end{array}$ & - \\
\hline regional_market & $\begin{array}{l}\text { The local/regional market at home is sufficiently large } \\
\text { (firm assessments on a five point scale: value } 1 \text { for scores } 4 \text { or } 5 \text {, otherwise } 0 \text { ) }\end{array}$ & - \\
\hline industry & Industry dummies (2-digit) in manufacturing (16) and services (9) & \\
\hline
\end{tabular}


Table 4: Model I (INT_propensity): Firms with "domestic sales only" (DOMESTIC) and those with "direct foreign activity" (FDI), evaluated against the reference group of firms with "export and domestic sales only" (EXPORT); multinomial logit estimates a, b

\begin{tabular}{|c|c|c|c|c|c|c|}
\hline \multirow[b]{2}{*}{ Explanatory variable } & \multicolumn{2}{|c|}{ Total business sector ${ }^{\mathrm{c}}$} & \multicolumn{2}{|c|}{ Manufacturing } & \multicolumn{2}{|c|}{ Services } \\
\hline & DOMESTIC & FDI & DOMESTIC & FDI & DOMESTIC & FDI \\
\hline \multicolumn{7}{|l|}{ O-advantages } \\
\hline$r \& d$ & $\begin{array}{c}-.708 * * * \\
(.19)\end{array}$ & $\begin{array}{c}.823 * * * \\
(.18)\end{array}$ & $\begin{array}{c}-.707 * * * \\
(.26)\end{array}$ & $\begin{array}{c}.883 * * * \\
(.22)\end{array}$ & $\begin{array}{l}-.508 \\
(.35)\end{array}$ & $\begin{array}{c}.868^{* *} \\
(.39)\end{array}$ \\
\hline inno_sales & $\begin{array}{l}.050 \\
(.06)\end{array}$ & $\begin{array}{c}.177 * * * \\
(.06)\end{array}$ & $\begin{array}{l}.022 \\
(.08)\end{array}$ & $\begin{array}{c}.182^{* *} \\
(.08)\end{array}$ & $\begin{array}{l}.057 \\
(.08)\end{array}$ & $\begin{array}{l}.167 \\
(.11)\end{array}$ \\
\hline tertiary_academic & $\begin{array}{c}-.257 * * * \\
(.06)\end{array}$ & $\begin{array}{c}.187 * * * \\
(.07)\end{array}$ & $\begin{array}{c}-.286^{* *} \\
(.11)\end{array}$ & $\begin{array}{l}.125 \\
(.09)\end{array}$ & $\begin{array}{c}-.274 * * * \\
(.08)\end{array}$ & $\begin{array}{l}.195^{*} \\
(.12)\end{array}$ \\
\hline appropriability & $\begin{array}{c}-.276^{* * *} \\
(.08)\end{array}$ & $\begin{array}{l}.015 \\
(.09)\end{array}$ & $\begin{array}{c}-.197 * \\
(.12)\end{array}$ & $\begin{array}{c}-.004 \\
(.11)\end{array}$ & $\begin{array}{c}-.248^{*} \\
(.13)\end{array}$ & $\begin{array}{l}.072 \\
(.17)\end{array}$ \\
\hline firm_age & $\begin{array}{l}.074 \\
(.09)\end{array}$ & $\begin{array}{c}.350 * * * \\
(.10)\end{array}$ & $\begin{array}{l}.139 \\
(.14)\end{array}$ & $\begin{array}{c}.445^{* * * *} \\
(.13)\end{array}$ & $\begin{array}{c}-.043 \\
(.13)\end{array}$ & $\begin{array}{l}.201 \\
(.17)\end{array}$ \\
\hline \multicolumn{7}{|l|}{ O-related obstacles } \\
\hline obst_experience & $\begin{array}{c}.449 * * \\
(.20)\end{array}$ & $\begin{array}{c}-.473 * * \\
(.22)\end{array}$ & $\begin{array}{l}.446 \\
(.28)\end{array}$ & $\begin{array}{c}-.643 * * \\
(.29)\end{array}$ & $\begin{array}{c}.740 * * \\
(.31)\end{array}$ & $\begin{array}{l}.044 \\
(.43)\end{array}$ \\
\hline \multicolumn{7}{|l|}{$\begin{array}{l}\text { L-(dis)advantages / } \\
\text { L-related obstacles }\end{array}$} \\
\hline obst_distance & $\begin{array}{l}.044 \\
(.19)\end{array}$ & $\begin{array}{c}-.422 * * \\
(.22)\end{array}$ & $\begin{array}{l}-.252 \\
(.28)\end{array}$ & $\begin{array}{c}-.351 \\
(.27)\end{array}$ & $\begin{array}{l}.525^{*} \\
(.31)\end{array}$ & $\begin{array}{l}-.501 \\
(.46)\end{array}$ \\
\hline obst_culture & $\begin{array}{l}.138 \\
(.24)\end{array}$ & $\begin{array}{c}.842 * * * \\
(.24)\end{array}$ & $\begin{array}{l}.309 \\
(.37)\end{array}$ & $\begin{array}{c}1.26 * * * \\
(.32)\end{array}$ & $\begin{array}{c}-.176 \\
(.34)\end{array}$ & $\begin{array}{l}.175 \\
(.43)\end{array}$ \\
\hline obst_cost & $\begin{array}{c}-.279 \\
(.18)\end{array}$ & $\begin{array}{c}-.565 * * * \\
(.19)\end{array}$ & $\begin{array}{c}-.077 \\
(.24)\end{array}$ & $\begin{array}{c}-.445^{*} \\
(.24)\end{array}$ & $\begin{array}{c}-.858 * * * \\
(.28)\end{array}$ & $\begin{array}{c}-.846^{* *} \\
(.38)\end{array}$ \\
\hline obst_regulation & $\begin{array}{l}.204 \\
(.22)\end{array}$ & $\begin{array}{c}.684 * * * \\
(.22)\end{array}$ & $\begin{array}{l}.087 \\
(.37)\end{array}$ & $\begin{array}{c}.806 * * * \\
(.29)\end{array}$ & $\begin{array}{l}.221 \\
(.32)\end{array}$ & $\begin{array}{l}.563 \\
(.41)\end{array}$ \\
\hline obst_instability & $\begin{array}{l}-.160 \\
(.25)\end{array}$ & $\begin{array}{l}.345 \\
(.23)\end{array}$ & $\begin{array}{c}-.393 \\
(.38)\end{array}$ & $\begin{array}{l}.163 \\
(.29)\end{array}$ & $\begin{array}{l}.009 \\
(.39)\end{array}$ & $\begin{array}{l}.554 \\
(.45)\end{array}$ \\
\hline obst_local_value & $\begin{array}{l}.024 \\
(.27)\end{array}$ & $\begin{array}{c}-.506^{* *} \\
(.26)\end{array}$ & $\begin{array}{l}.070 \\
(.38)\end{array}$ & $\begin{array}{c}-.476 \\
(.33)\end{array}$ & $\begin{array}{l}.043 \\
(.41)\end{array}$ & $\begin{array}{c}-.473 \\
(.56)\end{array}$ \\
\hline obst_tech_transfer & $\begin{array}{c}-.180 \\
(.37)\end{array}$ & $\begin{array}{c}-.575^{* *} \\
(.29)\end{array}$ & $\begin{array}{c}-.120 \\
(.50)\end{array}$ & $\begin{array}{c}-.756^{* *} \\
(.35)\end{array}$ & $\begin{array}{l}.021 \\
(.61)\end{array}$ & $\begin{array}{c}-.447 \\
(.75)\end{array}$ \\
\hline obst_IPR_protection & $\begin{array}{l}.248 \\
(.34)\end{array}$ & $\begin{array}{c}.510^{*} \\
(.28)\end{array}$ & $\begin{array}{l}.176 \\
(.46)\end{array}$ & $\begin{array}{c}.925 * * * \\
(.33)\end{array}$ & $\begin{array}{c}-.247 \\
(.51)\end{array}$ & $\begin{array}{c}-1.04 \\
(.73) \\
\end{array}$ \\
\hline $\begin{array}{l}\text { I-advantages / } \\
\text { firm size } \\
\text { size }\end{array}$ & $\begin{array}{l}2 \mathrm{E}-05 \\
(2 \mathrm{E}-04)\end{array}$ & $\begin{array}{c}6 \mathrm{E}-04 * * * \\
(2 \mathrm{E}-04)\end{array}$ & $\begin{array}{l}-6 \mathrm{E}-04 \\
(9 \mathrm{E}-04)\end{array}$ & $\begin{array}{c}1 \mathrm{E}-03 * * * \\
(5 \mathrm{E}-04)\end{array}$ & $\begin{array}{l}6 \mathrm{E}-05 \\
(3 \mathrm{E}-04))\end{array}$ & $\begin{array}{l}3 \mathrm{E}-04 \\
(3 \mathrm{E}-04)\end{array}$ \\
\hline $\operatorname{size}^{2}$ & $\begin{array}{l}-1 \mathrm{E}-07 \\
(4 \mathrm{E}-06)\end{array}$ & $\begin{array}{c}-9 \mathrm{E}-06 * * \\
(4 \mathrm{E}-06)\end{array}$ & $\begin{array}{l}-7 \mathrm{E}-05 \\
(2 \mathrm{E}-04))\end{array}$ & $\begin{array}{c}-1 \mathrm{E}-04 * * \\
(5 \mathrm{E}-05))\end{array}$ & $\begin{array}{l}2 \mathrm{E}-06 \\
(3 \mathrm{E}-05)\end{array}$ & $\begin{array}{l}-1 \mathrm{E}-06 \\
(3 \mathrm{E}-05))\end{array}$ \\
\hline cooperation & $\begin{array}{c}-.029 \\
(.15) \\
\end{array}$ & $\begin{array}{c}.262 * \\
(.15) \\
\end{array}$ & $\begin{array}{l}.162 \\
(.23) \\
\end{array}$ & $\begin{array}{c}.448^{* *} \\
(.19) \\
\end{array}$ & $\begin{array}{c}-.315 \\
(.21) \\
\end{array}$ & $\begin{array}{c}-.061 \\
(.28) \\
\end{array}$ \\
\hline \multicolumn{7}{|l|}{ Market conditions } \\
\hline competition & $\begin{array}{c}-.294 \\
(.61)\end{array}$ & $\begin{array}{c}1.25^{*} \\
(.70)\end{array}$ & $\begin{array}{c}-.584 \\
(1.1)\end{array}$ & $\begin{array}{l}.989 \\
(1.2)\end{array}$ & $\begin{array}{c}-.020 \\
(.74)\end{array}$ & $\begin{array}{c}2.15^{* *} \\
(.92)\end{array}$ \\
\hline demand_trend & $-2.48 * * *$ & 1.20 & $-3.81 * * *$ & 1.43 & -.862 & $3.08 * *$ \\
\hline
\end{tabular}




\begin{tabular}{|c|c|c|c|c|c|c|}
\hline & (.65) & (.76) & $(1.0)$ & (1.1) & (.91) & (1.3) \\
\hline \multicolumn{7}{|l|}{ Control variables } \\
\hline foreign & $\begin{array}{c}-.117 \\
(.20)\end{array}$ & $\begin{array}{c}-2.08 * * * \\
(.28)\end{array}$ & $\begin{array}{c}-.192 \\
(.32)\end{array}$ & $\begin{array}{c}-2.18 * * * \\
(.37)\end{array}$ & $\begin{array}{c}-.118 \\
(.29)\end{array}$ & $\begin{array}{c}-2.06 * * * \\
(.48)\end{array}$ \\
\hline regional_market & $\begin{array}{c}1.26 * * * \\
(.14)\end{array}$ & $\begin{array}{c}-.979 * * * \\
(.18)\end{array}$ & $\begin{array}{c}1.53 * * * \\
(.21)\end{array}$ & $\begin{array}{c}-.704 * * * \\
(.25)\end{array}$ & $\begin{array}{c}1.05 * * * \\
(.23)\end{array}$ & $\begin{array}{c}-1.18 * * * \\
(.30)\end{array}$ \\
\hline industry & \multicolumn{2}{|c|}{ Yes } & \multicolumn{2}{|c|}{ Yes } & \multicolumn{2}{|c|}{ Yes } \\
\hline $\begin{array}{l}\mathrm{N} \\
\text { Wald } \chi^{2} \\
\text { Pseudo } \mathrm{R}^{2}\end{array}$ & \multicolumn{2}{|c|}{$\begin{array}{c}1 ' 921 \\
3851.6^{* * * *} \\
.338\end{array}$} & \multicolumn{2}{|c|}{$\begin{array}{c}1 ’ 000 \\
1072.8 * * * \\
.332\end{array}$} & \multicolumn{2}{|c|}{$\begin{array}{c}757 \\
1786 * * * \\
.246\end{array}$} \\
\hline
\end{tabular}

${ }^{a}$ The multinomial logit model estimates for each explanatory variable two slope parameters what allows to evaluate whether the responses DOMESTIC and FDI respectively significantly differ from the reference level EXPORT.

${ }^{b}$ The estimates of the intercepts and the industry dummies have been throughout omitted. The significance of the parameters is indicated with $* * *, * *$ and $*$ resp. representing the $1 \%, 5 \%$ and $10 \%$-level with robust standard errors in brackets.

${ }^{c}$ The construction/energy sector $(\mathrm{N}=164)$ is included in the estimates for the total business sector $(\mathrm{N}=1921)$ but excluded in case of manufacturing $(\mathrm{N}=1000)$ and services $(\mathrm{N}=757)$. 
Table 5: Model II (INT_complexity): Firms with "direct foreign activity in research\& development and distribution and/or production" (FDI_RDP), evaluated against the reference group of firms with "direct foreign distribution and/or production" (FDI_DP); multinomial logit estimates ${ }^{\mathrm{a}, \mathrm{b}, \mathrm{c}}$

\begin{tabular}{|c|c|c|c|c|}
\hline & $\begin{array}{l}\text { Total business } \\
\text { sector }\end{array}$ & Manufacturing & Services & Services \\
\hline Explanatory variable & FDI_RDP & FDI_RDP & FDI_RDP & FDI_RDP \\
\hline \multicolumn{5}{|l|}{ O-advantages } \\
\hline$r \& d$ & $\begin{array}{c}2.02 * * * \\
(.46)\end{array}$ & $\begin{array}{c}1.35^{* *} \\
(.52)\end{array}$ & $\begin{array}{c}3.77 * * * \\
(1.1)\end{array}$ & \\
\hline inno_sales & $\begin{array}{c}.281 * * * \\
(.11)\end{array}$ & $\begin{array}{c}.301^{* *} \\
(.13)\end{array}$ & $\begin{array}{l}.435 \\
(.36)\end{array}$ & $\begin{array}{l}.444^{*} \\
(.24)\end{array}$ \\
\hline tertiary_academic & $\begin{array}{l}.050 \\
(.11)\end{array}$ & $\begin{array}{l}.238^{* *} \\
(.12)\end{array}$ & $\begin{array}{c}-.667 * * * \\
(.27)\end{array}$ & $\begin{array}{l}-.280 \\
(.26)\end{array}$ \\
\hline appropriability & $\begin{array}{c}.464 * * * \\
(.15)\end{array}$ & $\begin{array}{c}.620 * * * \\
(.17)\end{array}$ & $\begin{array}{l}.286 \\
(.40)\end{array}$ & $\begin{array}{l}.288 \\
(.34)\end{array}$ \\
\hline firm_age & $\begin{array}{l}.134 \\
(.16)\end{array}$ & $\begin{array}{l}.178 \\
(.18)\end{array}$ & $\begin{array}{c}-.304 \\
(.48)\end{array}$ & $\begin{array}{l}.241 \\
(.35)\end{array}$ \\
\hline $\begin{array}{l}\text { O-related obstacles } \\
\text { obst_experience }\end{array}$ & $\begin{array}{l}-.504 \\
(.42) \\
\end{array}$ & $\begin{array}{c}-.926^{*} \\
(.50)\end{array}$ & $\begin{array}{c}1.44^{*} \\
(.81)\end{array}$ & $\begin{array}{c}0.577 \\
(.78)\end{array}$ \\
\hline \multicolumn{5}{|l|}{$\begin{array}{l}\text { L-(dis)advantages / } \\
\text { L-related obstacles }\end{array}$} \\
\hline obst_distance & $\begin{array}{l}-.493 \\
(.36)\end{array}$ & $\begin{array}{c}-.266 \\
(.38)\end{array}$ & $\begin{array}{c}-2.23^{* *} \\
(1.0)\end{array}$ & $\begin{array}{c}-1.59 * \\
(.90)\end{array}$ \\
\hline obst_culture & $\begin{array}{l}.249 \\
(.34)\end{array}$ & $\begin{array}{l}.213 \\
(.37)\end{array}$ & $\begin{array}{l}1.19 \\
(0.81)\end{array}$ & $\begin{array}{c}0.564 \\
(.82)\end{array}$ \\
\hline obst_cost & $\begin{array}{l}-.243 \\
(.31)\end{array}$ & $\begin{array}{l}-.534 \\
(.34)\end{array}$ & $\begin{array}{l}1.04 \\
(.82)\end{array}$ & $\begin{array}{l}1.49 \\
(.88)\end{array}$ \\
\hline obst_regulation & $\begin{array}{l}.024 \\
(.29)\end{array}$ & $\begin{array}{l}.224 \\
(.31)\end{array}$ & $\begin{array}{l}.410 \\
(.75)\end{array}$ & $\begin{array}{l}.080 \\
(.66)\end{array}$ \\
\hline obst_instability & $\begin{array}{c}.918 * * * \\
(.32)\end{array}$ & $\begin{array}{c}.964 * * * \\
(.35)\end{array}$ & $\begin{array}{l}1.20 \\
(.93)\end{array}$ & $\begin{array}{c}1.24^{*} \\
(.66)\end{array}$ \\
\hline obst_local_value & $\begin{array}{c}-.420 \\
(.37)\end{array}$ & $\begin{array}{c}-.287 \\
(.40)\end{array}$ & $\begin{array}{c}-3.83 * * * \\
(1.4)\end{array}$ & $\begin{array}{c}-3.71 * * * \\
(1.5)\end{array}$ \\
\hline obst_tech_transfer & $\begin{array}{l}.024 \\
(.37)\end{array}$ & $\begin{array}{c}-.219 \\
(.38)\end{array}$ & $\begin{array}{l}.684 \\
(1.3)\end{array}$ & $\begin{array}{l}1.63 \\
(1.1)\end{array}$ \\
\hline obst_IPR_protection & $\begin{array}{c}.927 * * * \\
(.33)\end{array}$ & $\begin{array}{c}1.12 * * * \\
(.37)\end{array}$ & $\begin{array}{r}-.854 \\
(1.11)\end{array}$ & $\begin{array}{c}-.124 \\
(1.0)\end{array}$ \\
\hline $\begin{array}{l}\text { I-advantages / } \\
\text { Firm size } \\
\text { size }\end{array}$ & $\begin{array}{c}9 \mathrm{E}-04 * * * \\
(3 \mathrm{E}-04)\end{array}$ & $\begin{array}{l}\text { 7E-04* } \\
(4 \mathrm{E}-04)\end{array}$ & $\begin{array}{l}6 \mathrm{E}-04 * \\
(4-04))\end{array}$ & $\begin{array}{c}6 \mathrm{E}-04 * * \\
(3 \mathrm{E}-04))\end{array}$ \\
\hline $\operatorname{size}^{2}$ & $\begin{array}{l}-8 \mathrm{E}-05^{* *} \\
(3 \mathrm{E}-05)\end{array}$ & $\begin{array}{l}-4 \mathrm{E}-05 \\
(4 \mathrm{E}-05)\end{array}$ & $\begin{array}{c}-5 \mathrm{E}-05^{*} \\
(3 \mathrm{E}-05)\end{array}$ & $\begin{array}{c}-4 \mathrm{E}-05^{*} \\
(2 \mathrm{E}-05)\end{array}$ \\
\hline cooperation & .301 & .162 & $1.69^{* *}$ & $1.71 * *$ \\
\hline
\end{tabular}




\begin{tabular}{|l|c|c|cc|} 
& $(.23)$ & $(.27)$ & $(0.82)$ & $(.70)$ \\
\hline Market conditions & & & & \\
competition & .094 & .579 & 4.21 & 4.44 \\
& $(1.3)$ & $(1.5)$ & $(3.1)$ & $(2.6)$ \\
demand_trend & .337 & .418 & -2.84 & -3.27 \\
& $(1.1)$ & $(1.2)$ & $(3.3)$ & $(2.7)$ \\
\hline Control variables & & & & \\
foreign_subsidiary & -.083 & -.177 & 0.068 & -.092 \\
& $(.55)$ & $(.65)$ & $(1.08)$ & $(1.08)$ \\
regional_market & -.536 & -.446 & -1.00 & -0.894 \\
& $(.43)$ & $(.52)$ & $(.77)$ & Yes \\
industry dummies & yes & yes & yes & 757 \\
\hline N & 1921 & 1000 & 757 & $4666.8^{* * *}$ \\
Wald $\chi^{2}$ & $12879.2^{* * *}$ & $3043.4^{* * *}$ & $5005.7^{* * *}$ & 0.252 \\
Pseudo $\mathrm{R}^{2}$ & 0.336 & 0.323 & 0.276 & \\
\hline
\end{tabular}

${ }^{a}$ The multinomial logit model yields estimates for the categories DOMESTIC, EXPORT, FDI_DP and FDI_RDP, respectively. We present here only the estimates of the slope parameters for category FDI_RDP which are evaluated against the reference level FDI DP.

${ }^{b}$ The estimates of the intercepts and the industry dummies have been throughout omitted. The significance of the parameters is indicated with $* * *, * *$ and $*$ resp. representing the $1 \%, 5 \%$ and $10 \%$-level with robust standard errors in brackets.

${ }^{c}$ The construction/energy sector $(\mathrm{N}=164)$ is included in the estimates for the total business sector $(\mathrm{N}=1921)$ but excluded in case of manufacturing $(\mathrm{N}=1000)$ and services $(\mathrm{N}=757)$. 


\section{Appendix}

Table A.1: Composition of the final sample by sector and firm size

\begin{tabular}{|c|c|c|c|c|c|c|}
\hline & \multicolumn{2}{|c|}{ Sector } & \multicolumn{4}{|c|}{$\begin{array}{l}\text { Firm size (number of employees); } \\
\text { (percentage of firms) }\end{array}$} \\
\hline & $\begin{array}{l}\text { Number of } \\
\text { observations }\end{array}$ & $\begin{array}{l}\text { Percentage } \\
\text { of firms }\end{array}$ & $\begin{array}{l}\text { Small } \\
(5-49)\end{array}$ & $\begin{array}{l}\text { Medium } \\
(50-249)\end{array}$ & $\begin{array}{c}\text { Large } \\
(50 \text { and more })\end{array}$ & Total \\
\hline Manufacturing & 1000 & 52.0 & 37.4 & 42.0 & 20.6 & 100 \\
\hline $\begin{array}{ll}- & \text { High-tech } \\
\text { - } & \text { Low-tech }\end{array}$ & $\begin{array}{l}494 \\
506\end{array}$ & $\begin{array}{l}25.7 \\
26.3\end{array}$ & $\begin{array}{l}35.4 \\
39.3\end{array}$ & $\begin{array}{l}42.9 \\
41.1\end{array}$ & $\begin{array}{l}21.7 \\
19.6\end{array}$ & $\begin{array}{l}100 \\
100\end{array}$ \\
\hline Services & 757 & 39.4 & 44.1 & 32.9 & 23.0 & 100 \\
\hline $\begin{array}{ll}\text { - } & \text { Knowledge-intensive services } \\
\text { - } & \text { Other services }\end{array}$ & $\begin{array}{l}317 \\
440\end{array}$ & $\begin{array}{l}16.5 \\
22.9\end{array}$ & $\begin{array}{l}49.2 \\
40.5\end{array}$ & $\begin{array}{l}29.7 \\
35.2\end{array}$ & $\begin{array}{l}21.1 \\
24.3\end{array}$ & $\begin{array}{l}100 \\
100\end{array}$ \\
\hline Total business sector & 1921 & 100 & 38.7 & 39.4 & 21.9 & 100 \\
\hline
\end{tabular}

High-tech manufacturing: pharmaceuticals/chemicals, rubber/plastic products, non-electrical machinery, electrical machinery, electronics/instruments, vehicles; Low-tech manufacturing: food/beverages, textiles, clothing, wood products, paper, printing/publishing, non-metallic mineral products, metals, metal products, watches, other manufacturing; Knowledge-intensive services banking/insurance, computer services/R\&D, business services, telecommunication; Other services: wholesale trade, retail trade, hotels/restaurants, transport/logistics, real estate, personal services. 
Table A.2: Type and degree of internationalisation by sector and industry

\begin{tabular}{|c|c|c|c|c|}
\hline Industry / sectors & $\begin{array}{l}\text { Domestic sales } \\
\text { only }\end{array}$ & $\begin{array}{l}\text { Domestic sales } \\
\text { and exports } \\
\text { only }\end{array}$ & $\begin{array}{l}\text { Direct foreign } \\
\text { presence }\end{array}$ & \\
\hline Manufacturing & 25.2 & 36.3 & 38.5 & 100 \\
\hline High-tech manufacturing & 13.0 & 34.8 & 52.2 & 100 \\
\hline - Pharmaceuticals, chemicals & 13.4 & 37.8 & 48.8 & 100 \\
\hline - Rubber/plastics products & 7.0 & 48.8 & 44.2 & 100 \\
\hline - Non-electrical machinery & 12.5 & 30.7 & 56.8 & 100 \\
\hline - Electrical machinery & 13.6 & 35.6 & 50.8 & 100 \\
\hline - Electronics/instruments & 15.9 & 30.1 & 54.0 & 100 \\
\hline - Vehicles & 9.5 & 52.4 & 38.1 & 100 \\
\hline Low-tech manufacturing & 37.2 & 37.7 & 25.1 & 100 \\
\hline - Food/beverages/tobacco & 44.4 & 31.5 & 24.1 & 100 \\
\hline - Textiles & 17.9 & 35.7 & 46.4 & 100 \\
\hline - Clothing & 42.9 & 42.9 & 14.2 & 100 \\
\hline - Wood products & 35.3 & 41.2 & 23.5 & 100 \\
\hline - Paper & 15.4 & 38.4 & 46.2 & 100 \\
\hline - Printing/publishing & 64.4 & 28.9 & 6.7 & 100 \\
\hline - Non-metallic mineral products & 53.9 & 33.3 & 12.8 & 100 \\
\hline - Metals & 12.9 & 51.6 & 35.5 & 100 \\
\hline - Metal products & 30.8 & 43.9 & 25.3 & 100 \\
\hline - Watches & 32.4 & 47.0 & 20.6 & 100 \\
\hline - Other manufacturing & 36.8 & 26.3 & 36.9 & 100 \\
\hline Energy, construction & 83.0 & 8.5 & 8.5 & 100 \\
\hline - Energy/water/recycling & 37.5 & 0 & 62.5 & 100 \\
\hline - Construction & 85.3 & 8.9 & 5.8 & 100 \\
\hline Services & 58.9 & 21.8 & 19.3 & 100 \\
\hline Knowledge-intensive services & 53.0 & 22.4 & 21.4 & 100 \\
\hline - Banking/insurance & 49.4 & 29.5 & 21.1 & 100 \\
\hline - Computer services/R\&D & 40.0 & 24.0 & 36.0 & 100 \\
\hline - Business services & 58.7 & 17.5 & 23.8 & 100 \\
\hline - Telecommunication & 58.3 & 25.0 & 16.7 & 100 \\
\hline Other services & 63.1 & 21.4 & 15.5 & 100 \\
\hline - Wholesale trade & 62.6 & 19.7 & 17.7 & 100 \\
\hline - Retail trade & 71.1 & 8.9 & 20.0 & 100 \\
\hline - Hotels/restaurants & 43.5 & 43.5 & 13.0 & 100 \\
\hline - Transport/logistics & 61.8 & 25.5 & 12.7 & 100 \\
\hline - Real estate & 100 & 0 & 0 & 100 \\
\hline - Personal services & 100 & 0 & 0 & 100 \\
\hline TOTAL & $\begin{array}{c}43.4 \\
(N=834)\end{array}$ & $\begin{array}{c}28.2 \\
(N=542)\end{array}$ & $\begin{array}{c}28.4 \\
(N=545)\end{array}$ & $\begin{array}{c}100 \\
(N=1921)\end{array}$ \\
\hline
\end{tabular}


Table A.4: Descriptive statistics

\begin{tabular}{|l|ccccr|}
\hline Variable & $\mathrm{N}$ & Mean & $\begin{array}{c}\text { Standard } \\
\text { deviation }\end{array}$ & Minimum & Maximum \\
\hline INT_propensity & 1921 & 1.848 & 0.833 & 1 & 3 \\
INT_complexity & 1921 & 2.214 & 1.266 & 1 & 4 \\
\hline r\&d & 1921 & 0.346 & 0.476 & 0 & 1 \\
inno_sales & 1921 & 1.355 & 1.338 & 0 & 4.605 \\
tertiary_academic & 1921 & 1.112 & 1.239 & 0 & 4.605 \\
appropriability & 1921 & 2.207 & 0.934 & 1 & 5 \\
firm_age & 1921 & 3.835 & 0.793 & 0 & 5.864 \\
obst_experience & 1921 & 0.175 & 0.380 & 0 & 1 \\
\hline obst_distance & 1921 & 0.196 & 0.397 & 0 & 1 \\
obst_culture & 1921 & 0.153 & 0.360 & 0 & 1 \\
obst_cost & 1921 & 0.232 & 0.422 & 0 & 1 \\
obst_regulation & 1921 & 0.181 & 0.385 & 0 & 1 \\
obst_instability & 1921 & 0.146 & 0.353 & 0 & 1 \\
obst_local_value & 1921 & 0.103 & 0.303 & 0 & 1 \\
obst_tech_trans & 1921 & 0.084 & 0.277 & 0 & 1 \\
obst_protection & 1921 & 0.100 & 0.301 & 0 & 1 \\
\hline size & 1921 & 0.358 & 2.148 & 0.001 & 62.4 \\
cooperation & 1921 & 0.394 & 0.489 & 0 & 1 \\
\hline competition & 1921 & 0.682 & 0.148 & 0 & 1 \\
demand_trend & 1921 & 0.610 & 0.146 & 0 & 0.909 \\
\hline foreign_subsidiary & 1921 & 0.136 & 0.343 & 0 & 1 \\
regional_market & 1921 & 0.492 & 0.500 & 0 & 1 \\
\hline
\end{tabular}

